\title{
STRATEGI BISNIS PADA PT WIRAPATI GARUDA PAKSI
}

\author{
Rina Astini ${ }^{1}$; Rizcky Adhiprasetyo ${ }^{2}$ \\ ${ }^{1}$ Jurusan Manajemen, Fakultas Ekonomi, Universitas Mercu Buana, \\ Jln. Meruya Selatan, Kembangan Jakarta Barat 11650 \\ 2 Jurusan Manajemen, Fakultas Ekonomi dan Bisnis, Universitas Bina Nusantara, \\ Jln. K.H. Syahdan No. 9, Palmerah, Jakarta Barat 11480
}

\begin{abstract}
PT Garuda Wirapati Paksi (WGP) is a private corporation engaged in the Security and Rescue Services Business Sector (BUJPP) in guarding. Many challenges arise from the external environment such as unstable political and economic conditions, competition among companies and the entry of foreign firms. To face the above phenomenon, the right and effective business strategy is the right tool for avoiding the challenge. Business strategy planning is absolutely necessary for companies that want to survive in the future. The research method is descriptive. Data collection techniques used are questionnaire and interview with relevant parties within the company. The data have been obtained that, in the analysis through three phases, namely input, matching, and decision stage. The final results of this study concluded that the proposed effective business strategy for PT Garuda Wirapati Paksi based on QSPM matrix is Market Penetration Strategy. This strategy is considered to reduce business risk arising as a result of significant changes to the external environment of the company.
\end{abstract}

Keywords: business strategy, input stage, matching stage, decision stage

\begin{abstract}
ABSTRAK
PT Wirapati Garuda Paksi (WGP) adalah perusahaan swasta yang berbentuk perseroan terbatas dan bergerak di Bidang Usaha Jasa Pengamanan dan Penyelamatan (BUJPP) dalam penjagaan (guarding). Banyak tantangan timbul dari lingkungan eksternal seperti kondisi politik dan ekonomi yang tidak stabil, persaingan sesama perusahaan dan masuknya perusahaan asing. Untuk menghadapi fenomena di atas, strategi bisnis yang tepat dan efektif menjadi alat yang tepat untuk menghindari tantangan yang ada. Perencanaan strategi bisnis merupakan syarat mutlak bagi perusahaan yang ingin tetap bertahan di masa mendatang. Metode penelitian adalah deskriptif. Teknik pengumpulan data yang digunakan adalah kuesioner dan wawancara dengan pihakpihak yang terkait di dalam perusahaan. Data-data yang telah diperoleh tersebut, dianalisis melalui tiga tahap, yakni tahap masukan, pencocokan, dan keputusan. Hasil akhir penelitian ini disimpulkan bahwa usulan strategi bisnis yang efektif untuk PT Wirapati Garuda Paksi berdasarkan Matriks QSPM adalah Strategi Penetrasi Pasar, di mana strategi ini dinilai dapat mengurangi risiko bisnis perusahaan yang timbul akibat adanya perubahan yang signifikan pada lingkungan eksternal perusahaan.
\end{abstract}

Kata kunci: strategi bisnis, tahap masukan, tahap pencocokan, tahap keputusan 


\section{PENDAHULUAN}

Banyak strategi bisnis yang layak digunakan oleh perusahaan. Yang menjadi pertanyaan perusahaan terhadap strategi bisnis tersebut adalah "Manakah strategi yang tepat dan efektif terhadap perusahaan sesuai dengan situasi perusahaan dan industri yang dihadapi sekarang ini sehingga strategi bisnis tersebut berhasi?”. Melakukan perumusan strategi bisnis sehingga mendapatkan strategi bisnis yang efektif untuk perusahaan adalah cara yang sangat tepat untuk mencapai tujuan utama perusahaan sesuai dengan situasi yang dihadapi perusahaan saat ini. Cara yang dapat digunakan untuk melakukan perumusan strategi bisnis sehingga mendapatkan strategi bisnis yang tepat dan efektif adalah melihat faktor-faktor internal, yang meliputi kekuatan (strength) dan kelemahan (weekness) perusahaan dan faktor-faktor eksternal, yang meliputi peluang (opportunities) dan ancaman (threats) dari industri yang dihadapi perusahaan.

Untuk lebih jelas mengenai strategi bisnis yang dapat disarankan untuk perusahaan serta pengaruhnya terhadap instrumen perusahaan terhadap pemasok, jalur distribusi dan pemasarannya sehingga mendapatkan hasil dari tujuan utama perusahaan, melakukan studi terhadap perusahaan PT Wirapati Garuda Paksi. PT Wirapati Garuda Paksi (WGP) adalah sebuah perusahaan swasta yang bergerak dalam bidang penjaga (guarding), di mana seluruh produk yang diberikan berupa bidang jasa yang bergerak pada bidang jasa penyediaan tenaga pengamanan dan penyelamatan, jasa konsultasi keamanan, penyelidikan keamanan, dan jasa penerapan peralatan keamanan.

Proses perumusan strategi bisnis tersebut dimulai dari Tahap Masukan (Input Stage), yakni mengembangkan Matriks IFE (Internal Factor Evaluation), CPM (Competitive Profile Matrix), dan Matriks EFE (External Factor Evaluation). Selanjutnya, Tahap Pencocokan (Matching Stage), yakni menentukan alternatif strategi yang layak dengan menggunakan Matriks SWOT (Strength-WeeknessOpportunities-Threats), Matriks SPACE (Strategy Positioning And Action Evaluation), Matriks IE (Internal-External), dan Matriks Strategi Besar (Grand Strategy). Kemudian, Tahap Keputusan (decision stage), yakni merumuskan alternatif strategi yang terbaik dengan menggunakan Matriks QSPM (Quantitative Strategic Planning Matrix). Adapun masalah yang hendak dijawab melalui penelitian ini adalah (1) Bagaimana proses formulasi strategi bisnis PT Wirapati Garuda Paksi pada tahap masukan/input stage?, (2) Bagaimana proses formulasi strategi bisnis PT Wirapati Garuda Paksi pada tahap pencocokan/matching stage?, (3) Bagaimana proses formulasi strategi bisnis PT Wirapati Garuda Paksi pada tahap keputusan/decision stage?, (4) Apa usulan strategi bisnis yang efektif untuk PT Wirapati Garuda Paksi?.

Tujuan yang hendak dicapai lewat penelitian ini adalah menganalisis proses formulasi strategi bisnis PT Wirapati Garuda Paksi pada tahap masukan/input stage, tahap pencocokan/matching stage, dan tahap keputusan/decision stage serta memberikan usulan strategi bisnis yang efektif untuk PT Wirapati Garuda Paksi. Penelitian ini menggunakan konsep manajemen strategis seperti pada Gambar 1 di bawah ini. 


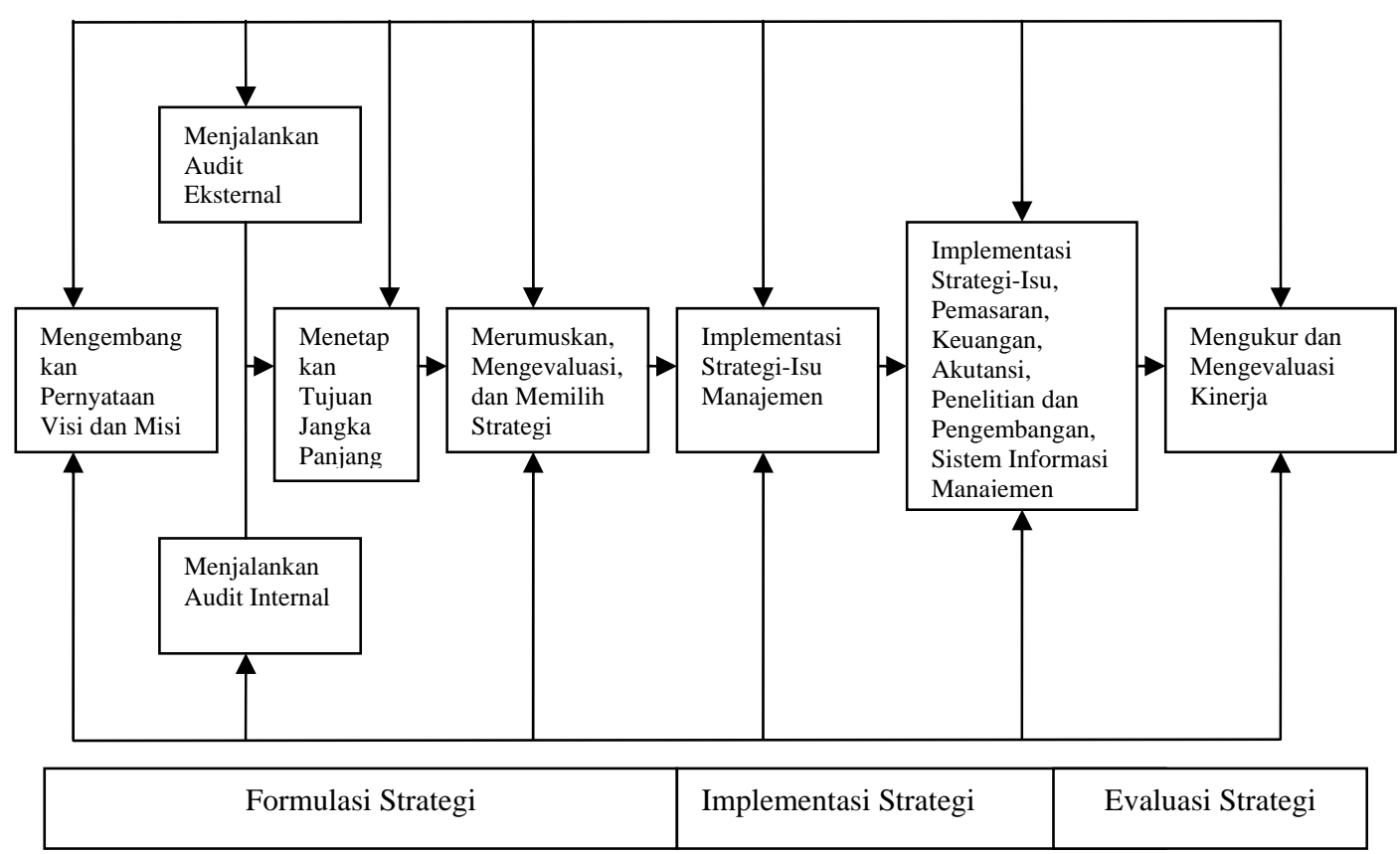

Gambar 1 Konsep Manajemen Strategis (David, 2006:19)

Menurut David (2006:144), pendekatan Porter atau sering disebut dengan analisis persaingan model lima kekuatan Porter merupakan pendekatan yang banyak dipakai untuk mengembangkan strategi oleh banyak industri. Intensitas persaingan antar perusahaan sangat beragam di berbagai industri. Intensitas persaingan paling tinggi adalah dalam industri dengan laba kecil. Menurut Porter, sifat persaingan dalam suatu industri dapat dilihat sebagai gabungan dari 5 kekuatan sebagai berikut (Gambar 2).

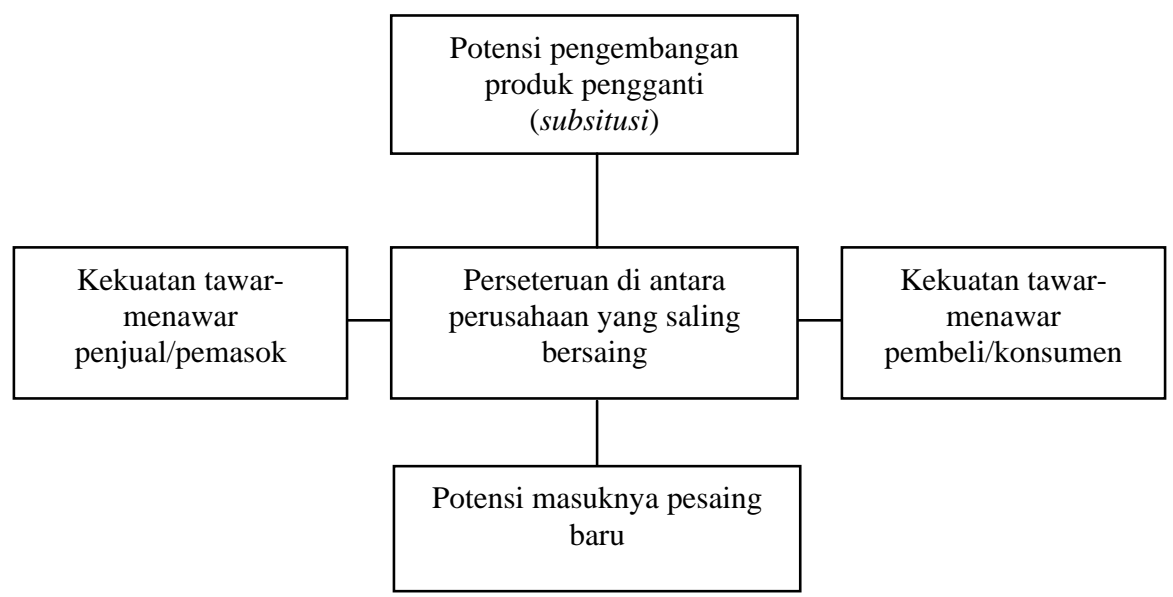

Sumber: buku Manajemen Strategi—Konsep (David, 2006:121)

Gambar 2 Gambar Model Lima Kekuatan Porter 
Pada kategori strategi, pertumbuhan/ekspansi (growth/expansion strategy) ini dijalankan perusahaan dalam rangka mengejar pertumbuhan korporat, yang dapat berupa kenaikan penjualan, profit, ekspansi usaha, dan lain-lain, yang akan berdampak pada pengembangan/pertumbuhan perusahaan. Berikut beberapa strategi yang termasuk pada kategori strategi pertumbuhan. Pertama, strategi integrasi (integration strategy). Forward integration, backward integration, dan horizontal integration merupakan 3 macam strategi yang termasuk dalam kelompok strategi integrasi, yaitu (1) Integrasi ke depan (forward integration) adalah strategi perusahaan untuk meningkatkan pengendalian terhadap sistem distribusi/jalur distribusi (integrasi ke hilir). Pengendalian sistem distribusi ini diperlukan dalam mengantisipasi masalah-masalah yang terjadi dalam jalur pendistribusian produk, (2) Integrasi ke belakang (backward integration) merupakan strategi untuk mendapatkan kepemilikan terhadap produk atau bahan baku. Strategi ini diperlukan untuk meningkatkan pengawasan yang lebih ketat terhadap supplier (integrasi hulu), dan (3) Integrasi horisontal (horizontal integration) adalah strategi yang bertujuan untuk meningkatkan pengawasan terhadap para pesaing, dengan demikian segmen pasar lebih mudah dikuasai/diperluas. Selain itu, strategi ini dapat dipergunakan untuk meningkatkan kapasitas produksi.

Kedua, strategi intensif (intensive strategy). Penetrasi pasar, pengembangan pasar, dan pengembangan produk kadang-kadang disebut sebagai strategi intensif (intensive strategies) karena mereka membutuhkan usaha intensif jika posisi kimpetitif perusahaan dengan produk saat ini akan membaik. Umumnya strategi ini memerlukan usaha-usaha yang intensif untuk meningkatkan posisi kompetitif perusahaan, yaitu (1) Penetrasi pasar adalah strategi yang bertujuan untuk meningkatkan atau mencari marketshare yang lebih besar bagi suatu produk. Hal ini dilakukan melalui usaha pemasaran yang lebih aktif. Strategi ini dapat dilakukan bila pasar masih belum jenuh terhadap produk yang ditawarkan. Strategi penetrasi pasar (market penetration) berusaha meningkatkan pangsa pasar untuk produk/jasa saat ini melalui upaya pemasaran yang lebih besar. Strategi penetrasi pasar mencakup meningkatnya jumlah tenaga penjual, meningkatnya jumlah belanja iklan, menawarkan promosi penjualan yang ekstensif, atau meningkatkan usaha publisitas; (2) Pengembangan pasar (market development) merupakan strategi yang berusaha untuk memperkenalkan produk atau jasa yang sudah ada pada daerah (geografis) baru serta memperluas jaringan distribusi. Strategi ini dapat dilakukan bila perusahaan memiliki jaringan distribusi yang kuat dan adanya peluang pasar baru sehingga memungkinkan untuk melakukan penambahan kapasitas produksi. Jadi, strategi ini dapat dilakukan dengan menambah saluran distribusi ke wilayah-wilayah pasar yang baru secara geografi; (3) Pengembangan produk (product development) adalah strategi yang bertujuan untuk meningkatkan penjualan dengan cara memperbaiki produk yang sudah ada dan atau mengembangkan produk yang baru. Strategi ini dapat dilakukan bila perusahaan memiliki kemampuan untuk membuat/ mengembangkan produk baru, di mana perekonomian sedang tumbuh dan pada kondisi ketika pesaing menawarkan produk yang semakin bersaing.

Ketiga, strategi diversifikasi (diversification strategy). Beberapa perusahaan cenderung untuk memiliki variasi bisnis yang berbeda. Strategi ini bertujuan agar perusahaan tidak hanya bergantung pada satu variabel usaha saja, namun juga dapat mengembangkan beberapa jenis usaha/industri lainnya. Ada 3 tipe umum dari strategi diversifikasi (diversification strategies), yaitu konsentrik (terfokus), horisontal, dan konglomerat. Secara keseluruhan, strategi diversifikasi telah berkurang kepopulerannya karena organisasi menemukan bahwa lebih sulit untuk mengelola aktivitas bisnis yang berbeda, yaitu (1) Diversifikasi konsentrik (concentric diversification) adalah strategi yang bertujuan untuk mengembangkan atau menambah produk/bisnis baru yang masih berhubungan dengan produk/bisnis lainnya. Strategi ini dapat dilakukan bila perusahaan sudah dalam tahap decline dan bersaing pada industri yang pertumbuhannya lambat; (2) Diversifikasi horisontal (horizontal diversification) Merupakan strategi yang bertujuan untuk mengembangkan atau menambah jenis produk baru/bisnis baru yang tidak berhubungan dengan produk/bisnis yang sudah ada. Strategi ini dapat dilakukan bila produk baru yang dihasilkan dapat mendukung produk yang sudah ada sebelumnya. Jadi, produk atau jasa yang baru tersebut akan dipasarkan kepada pelanggan yang sudah ada karena perusahaan telah mengerti dan mengenal kebutuhan pelanggan yang sudah ada; (3) 
Diversifikasi konglomerat adalah strategi yang menambahkan produk atau jasa baru, tapi tidak ada kaitannya dengan produk atau jasa yang sudah atau sedang dijalankan perusahaan saat ini. Dalam kondisi tertentu, perusahaan akan lebih memilih strategi defensif yang akan mempertahankan posisi yang ada saat ini atau karena kondisi yang terbatas, maka perusahaan paling tidak harus survive.

Keempat, strategi defensif (defensive strategy). Merupakan suatu strategi yang bertujuan agar perusahaan dapat menyelamatkan diri dari kerugian yang lebih besar. Berikut ini ada beberapa strategi defensif yang dapat diterapkan sesuai dengan urutan skala prioritas mulai dari strategi yang paling awal, yaitu strategi penghematan yang jika diterapkan tidak ada hasil, maka strategi berikutnya dalah divestasi jika strategi inipun tidak menolong perbaikan kondisi perusahaan, maka jalan dan strategi terakhir adalah likuidasi, yaitu (1) Penghematan (retrenchment/turnaround) merupakan strategi yang bertujuan untuk menghemat dan atau menghilangkan biaya, agar keuntungan perusahaan dapat dipertahankan dan atau ditingkatkan. Strategi ini dapat dilakukan bila kinerja/aktivitas perusahaan dinilai kurang efisien dan diperlukan reorganisasi internal karena perusahaan bertumbuh pesat; (2) Divestasi (divestiture) adalah strategi yang bertujuan untuk mendapatkan tambahan modal untuk suatu rencana investasi maupun untuk mengakuisisi perusahaan lain. Strategi ini dilakukan dengan cara menjual satu unit/sebagian dari aset suatu organisasi perusahaan. Hal ini dapat dilakukan pada saat kondisi perusahaan memerlukan tambahan modal atau bisa juga bila perusahaan merasa salah satu unit bisnisnya dalam kondisi rugi dan sudah tidak dapat dipertahankan lagi; (3) Likuidasi merupakan strategi yang bertujuan untuk menghentikan operasional perusahaan. Hal ini dilakukan karena terjadinya kerugian perusahaan yang cenderung bertambah besar atau perusahaan sudah tidak mempunyai peluang lagi untuk mempertahankan keberadaannya. Strategi ini dilakukan dengan cara menjual seluruh aset (berwujud) perusahaan dan menghentikan seluruh operasional perusahaan. Inti dari likuidasi sendiri adalah pengakuan atas kekalahan, konsekuensinya dapat menjadi strategi yang sulit secara emosional. Tetapi, mungkin lebih baik menghentikan operasi dibandingkan terus kehilangan sejumlah besar uang.

\section{METODE PENELITIAN}

Metode penelitian yang digunakan adalah studi kasus, yakni penelitian mengenai suatu objek tertentu, termasuk lingkungan dan kondisi masa lalunya secara terperinci selama kurun waktu tertentu. Dengan melakukan studi kasus, penelitian dapat lebih mendalam sehingga dapat menjawab keadaan itu terjadi atau diharapkan. Unit analisis dalam penelitian ini adalah perusahaan yakni PT Wirapati Garuda Paksi. Time horizon yang digunakan dalam penelitian ini adalah Cross Section, yaitu penelitian yang dilakukan, di mana data yang dikumpulkan hanya satu kali, dalam kurun waktu tertentu.

Tabel 1 Tabel Desain Penelitian

\begin{tabular}{ccccc}
\hline $\begin{array}{c}\text { Tujuan } \\
\text { Penelitian }\end{array}$ & $\begin{array}{c}\text { Jenis } \\
\text { Penelitian }\end{array}$ & $\begin{array}{c}\text { Metode yang } \\
\text { digunakan }\end{array}$ & $\begin{array}{c}\text { Unit } \\
\text { Analisis }\end{array}$ & $\begin{array}{c}\text { Time } \\
\text { Horizon }\end{array}$ \\
\hline T-1 & Deskriptif & Studi Kasus & Perusahaan & Cross Section \\
T-2 & Deskriptif & Studi Kasus & Perusahaan & Cross Section \\
T-3 & Deskriptif & Studi Kasus & Perusahaan & Cross Section \\
T-4 & Deskriptif & Studi Kasus & Perusahaan & Cross Section \\
\hline
\end{tabular}

Sumber: Hasil Penelitian (2009) 
Keterangan:

T-1 : Untuk menganalisis proses formulasi strategi bisnis PT Wirapati Garuda Paksi pada tahap masukan/input stage.

T-2 : Untuk menganalisis proses formulasi strategi bisnis PT Wirapati Garuda Paksi pada tahap pencocokan/matching stage.

T-3 : Untuk menganalisis proses formulasi strategi bisnis PT Wirapati Garuda Paksi pada tahap keputusan/decision stage.

T-4 : Untuk memberika usulan strategi bisnis yang efektif untuk PT Wirapati Garuda Paksi.

\section{Metode Analisis}

\section{Matriks Evaluasi Faktor Eksternal (EFE)}

Matriks Evaluasi Faktor Eksternal (External Factor Evaluation-EFE Matrix) memungkinkan para penyusun strategi untuk merangkum dan mengevaluasi informasi ekonomi, sosial, budaya, demografi, lingkungan, politik, pemerintah, hukum, teknologi, dan persaingan.

\section{Matriks Profil Kompetitif (CPM)}

Menurut David (2006:145-146), Matriks Profil Kompetitif (Competitive Profile Matrix$C P M$ ) mengidentifikasikan pesaing utama perusahaan serta kekuataan dan kelemahan mereka dalam hubungannya dengan posisi strategis dari perusahaan. Contoh, bobot dan total nilai tertimbang untuk CPM dan EFE memiliki arti yang sama. Tetapi, faktor penentu keberhasilan (critical success factorCSF) dalam CPM mencakup isu eksternal dan internal. Dengan demikian, peringkat mengacu pada kekuatan dan kelemahan, di mana $4=$ kekuatan utama, $3=$ kekuatan minor, $2=$ kelemahan minor, $1=$ kelemahan utama. Ada beberapa perbedaan penting antara EFE dan CPM.

\section{Matriks Evaluasi Faktor Internal (IFE)}

Tahap ekstraksi dalam menjalankan audit manajemen strategis adalah membuat Matriks Evaluasi Faktor Internal (Internal Factor Evaluation-EFE Matrix). Alat formulasi strategi ini meringkas dan mengevaluasi kekuatan dan kelemahan utama dalam area fungsional bisnis dan juga memberikan dasar untuk mengidentifikasi dan mengevaluasi hubungan antara area-area tersebut. Penilaian intuitif dibutuhkan untuk mengembangkan Matriks IFE, jadi kemunculan pendekatan ilmiah tidak seharusnya diartikan bahwa ini adalah teknik yang sangat luar biasa.

\section{Matriks Kekuatan-Kelemahan-Peluang-Ancaman (SWOT)}

Matriks Kekuatan-Kelemahan-Peluang-Ancaman (Strength-Weaknesses-OpportunitiesThreats-SWOT Matrix) adalah alat untuk mencocokkan yang penting yang membantu manajer mengembangkan 4 tipe strategi, yaitu SO (Kekuatan-Peluang-Strengths-Opportunities), WO (Kelemahan-Peluang-Weaknesses-Opportunities), ST (Kekuatan-Ancaman-Strengths-Threats), dan WT (Kelemahan-Ancaman-Weaknesses-Threats). Mencocokkan faktor eksternal dan internal kunci adalah bagian yang paling sulit dalam mengembangkan matriks SWOT dan membutuhkan penilaian yang baik.

\section{Matriks Evaluasi Posisi dan Tindakan Strategis (SPACE)}

Matriks Evaluasi Posisi dan Tindakan Strategis (Strategic Position and Action EvaluationSPACE Matrix) merupakan salah satu alat penting dalam pencocokan di tahap pencocokan. Kerangka kerja 4t kuadran dalam matriks SPACE mengindikasikan apakah strategi yang agresif, konservatif, defensif, atau kompetitif yang paling cocok dengan organisasi tertentu. Sumbu untuk matriks SPACE mewakili 2 dimensi internal, yaitu Kekuatan Keuangan (Financial Strength—FS) dan Keunggulan 
Kompetitif (Competitive Advantage-CA) dan 2 dimensi eksternal, yaitu Stabilitas Lingkungan (Enviromental Stability-ES) dan Kekuatan Industri (Industrial Strength-IS). Keempat faktor ini adalah penentu yang paling penting dari keseluruhan posisi strategis organisasi.

\section{Matriks Internal-Eksternal (IE)}

Matriks IE (Internal-External) memposisikan berbagai divisi organisasi dalam tampilan 9 sel. Matriks IE didasari pada 2 dimensi kunci, yaitu total rata-rata tertimbang IFE pada sumbu X dan total rata-rata tertimbang EFE pada sumbu Y. Masing-masing divisi dari sebuah organisasi harus membuat Matriks IFE dan EFE untuk bagian dari organisasi. Total rata-rata tertimbang yang diturunkan dari masing-masing divisi memungkinkan pembuatan Matriks IE tingkat korporasi. Pada sumbu $\mathrm{X}$ dari Matriks IE, total rata-rata tertimbang dari 1,0 hingga 1,99 dianggap rendah. Nilai dari 2,0 hingga 2,99 adalah menengah, dan nilai dari 3,0 hingga 4,0 adalah tinggi.

\section{Matriks Perencanaan Strategi Kuantitatif (QSPM)}

Di samping membuat peringkat strategi untuk menghasilkan daftar berprioritas, hanya ada satu teknik analisis dalam literatur yang didesain untuk menentukan daya tarik relatif dari alternatif tindakan yang layak. Teknik ini adalah Matriks Perencanaan Strategi Kuantitatif (Quantitative Strategic Planning Matrix-QSPM), yang termasuk dalam Tahap 3 dari kerangka kerja analisis perumusan strategi. Teknik ini secara objektif mengindikasikan alternatif strategi mana yang terbaik. QSPM menggunakan input daru analisis Tahap 1 dan hasil pencocokan dari analisis Tahap 2 untuk menentukan secara objektif di antara alternatif strategi, yaitu Matriks EFE, Matriks IFE, dan Matriks Profil Kompetitif (CPM) yang membentuk Tahap 1, digabungkan dengan Matriks SWOT, Matriks SPACE, Matriks IE, Matriks Grand Strategy, yang membentuk Tahap 2, memberikan informasi yang dibutuhkan untuk membuat QSPM (Tahap 3).

QSPM adalah alat yang memungkinkan penyusun strategi untuk mengevaluasi alternatif secara objektif, berdasarkan faktor keberhasilan kunci internal dan eksternal yang telah diidentifikasi sebelumnya seperti alat analisis perumusan strategi lainnya, QSPM membutuhkan penilaian intuitif yang baik.

\section{HASIL DAN PEMBAHASAN}

\section{Matriks Evaluasi Faktor Eksternal (EFE)}

Tabel 2 Tabel Matriks EFE PT. Wirapati Garuda Paksi

\begin{tabular}{llccc}
\hline No. & \multicolumn{1}{c}{ Faktor Eksternal Kunci } & Bobot & Peringkat & $\begin{array}{c}\text { Nilai } \\
\text { Tertimbang }\end{array}$ \\
\hline 1. & Pertambahan penduduk & 0.035 & 4 & 0.140 \\
2. & Permintaan jasa security meningkat & 0.097 & 4 & 0.388 \\
3. & Kerjasama dengan instansi yang dikelola oleh pemerintah & 0.083 & 3 & 0.249 \\
4. & Kesempatan membuat Balai Latihan Kerja (BLK) & 0.045 & 3 & 0.135 \\
5. & Keterlibatan Polri & 0.052 & 3 & 0.156 \\
6. & Kondisi politik yang tidak stabil & 0.163 & 2 & 0.326 \\
7. & Kondisi ekonomi yang tidak stabil & 0.204 & 3 & 0.612 \\
8. & Persaingan sesama sponsor & 0.037 & 2 & 0.074 \\
9. & Persaingan sesama perusahaan sejenis & 0.154 & 4 & 0.616 \\
10. & Masuknya perusahaan asing & 0.129 & 4 & 0.516 \\
\hline Total & Hasil Penelitian (2009) & 1.000 & & 3.212 \\
\hline \multicolumn{7}{r}{} \\
\end{tabular}




\section{Matriks Profil Kompetitif (CPM)}

Tabel 3 Tabel Matriks CPM PT Wirapati Garuda Paksi

\begin{tabular}{|c|c|c|c|c|c|c|c|}
\hline \multirow[t]{2}{*}{$\begin{array}{l}\text { Faktor } \\
\text { Penentu } \\
\text { Keberhasilan }\end{array}$} & \multirow[t]{2}{*}{ Bobot } & \multicolumn{2}{|c|}{$\begin{array}{l}\text { PT Wirapati } \\
\text { Garuda Paksi }\end{array}$} & \multicolumn{2}{|c|}{$\begin{array}{c}\text { PT Risk Management } \\
\text { Advisory (RMA) }\end{array}$} & \multicolumn{2}{|c|}{ PT ISS Facility } \\
\hline & & Peringkat & Nilai & Peringkat & Nilai & Peringkat & Nilai \\
\hline $\begin{array}{l}\text { Kualitas } \\
\text { Pelatih. }\end{array}$ & 0.036 & 3 & 0.108 & 3 & 0.108 & 4 & 0.144 \\
\hline $\begin{array}{l}\text { Kualitas } \\
\text { Karyawan. }\end{array}$ & 0.165 & 4 & 0.660 & 3 & 0.495 & 4 & 0.660 \\
\hline $\begin{array}{l}\text { Kerjasama } \\
\text { Polri. }\end{array}$ & 0.078 & 4 & 0.312 & 3 & 0.234 & 4 & 0.312 \\
\hline $\begin{array}{l}\text { Alat } \\
\text { pendukung } \\
\text { yang modern. }\end{array}$ & 0.047 & 4 & 0.188 & 3 & 0.141 & 4 & 0.188 \\
\hline $\begin{array}{l}\text { Memiliki } \\
\text { integritas. }\end{array}$ & 0.214 & 4 & 0.856 & 2 & 0.428 & 4 & 0.856 \\
\hline $\begin{array}{l}\text { Memiliki } \\
\text { integritas. }\end{array}$ & 0.214 & 4 & 0.856 & 2 & 0.428 & 4 & 0.856 \\
\hline $\begin{array}{l}\text { Manajemen } \\
\text { yang handal. }\end{array}$ & 0.203 & 3 & 0.609 & 4 & 0.812 & 4 & 0.812 \\
\hline $\begin{array}{l}\text { Marketing } \\
\text { yang handal. }\end{array}$ & 0.155 & 4 & 0.620 & 3 & 0.465 & 4 & 0.620 \\
\hline $\begin{array}{l}\text { Proses } \\
\text { penempatan } \\
\text { yang cepat. }\end{array}$ & 0.055 & 3 & 0.165 & 4 & 0.220 & 4 & 0.220 \\
\hline $\begin{array}{l}\text { Komisi } \\
\text { sponsor. }\end{array}$ & 0.026 & 1 & 0.026 & 1 & 0.026 & 4 & 0.104 \\
\hline $\begin{array}{l}\text { Pembayaran } \\
\text { komisi tepat } \\
\text { waktu. }\end{array}$ & 0.021 & 2 & 0.042 & 1 & 0.021 & 4 & 0.168 \\
\hline Total & 1.000 & & 3.586 & & 2.950 & & 4.084 \\
\hline
\end{tabular}

\section{Matriks Evaluasi Faktor Internal (IFE)}

Tabel 4 Tabel Matriks IFE PT. Wirapati Garuda Paksi

\begin{tabular}{clccc}
\hline No. & \multicolumn{1}{c}{ Faktor Internal Utama } & Bobot & Peringkat & $\begin{array}{c}\text { Nilai } \\
\text { Tertimbang }\end{array}$ \\
\hline 1. & Memiliki modal yang memadai & 0.180 & 4 & 0.720 \\
2. & Kredibilitas perusahaan yang baik & 0.261 & 4 & 1.044 \\
3. & Kerjasama yang baik dengan pihak Polri & 0.121 & 3 & 0.363 \\
4. & Pelatih yang terlatih dan berpengalaman & 0.027 & 4 & 0.108 \\
5. & Kerjasama dengan Jamsostek & 0.060 & 3 & 0.180 \\
6. & Pengendalian organisasi kurang efektif & 0.077 & 4 & 0.308 \\
7. & Tidak memiliki kantor cabang & 0.051 & 3 & 0.153 \\
8. & Tidak memiliki Balai Latihan Kerja (BLK) & 0.043 & 3 & 0.129 \\
9. & Sumber Daya Manusia (SDM) kurang memadai & 0.134 & 3 & 0.402 \\
10. & Tidak memaksimalkan media yang ada untuk melakukan & 0.046 & 3 & 0.138 \\
\hline \multicolumn{4}{c}{ Total } \\
\multicolumn{4}{c}{ Sumber: Hasil Penelitian Data (2009) } \\
\hline \multicolumn{2}{c}{1.000} \\
\end{tabular}




\section{Matriks Kekuatan-Kelemahan-Peluang-Ancaman (SWOT)}

Tabel 5 Tabel Matriks SWOT PT Wirapati Garuda Paksi

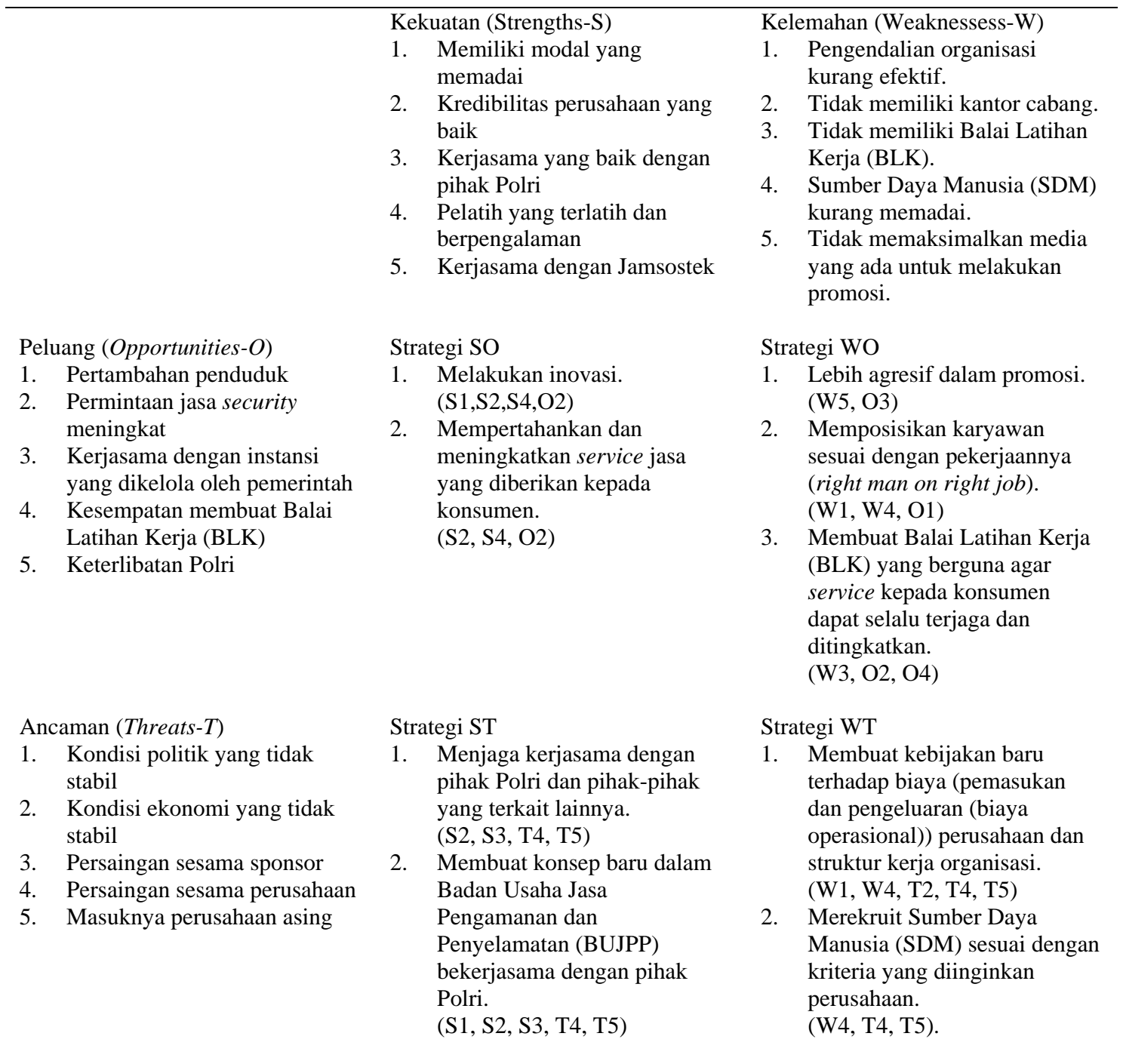

Sumber: Hasil Penelitian Data (2009) 


\section{Matriks Evaluasi Tindakan dan Posisi Strategi (SPACE)}

Tabel 6 Tabel Matriks SPACE PT Wirapati Garuda Paksi

\begin{tabular}{lc}
\hline \multicolumn{1}{c}{ Variabel } & Peringkat \\
\hline Kekuatan Keuangan (FS) & 5 \\
$\bullet \quad$ Tingkat permintaan security meningkat 50\% dari tahun sebelumnya. & 5 \\
Kekuatan Industri & \\
- Pangsa Pasar & 4 \\
- Pertumbuhan pasar tinggi & 3 \\
Stabilitas Lingkungan & 5 \\
- Inflasi & \\
Keunggulan kompetitif & -4 \\
$\bullet \quad$ Kualitas karyawan & -3 \\
- Integritas & \\
Kesimpulan & -1 \\
Rata-Rata IS $=12 / 3=4,00$ & -2 \\
Rata-Rata ES $=-7 / 2=-3.50$ & -2 \\
Rata-Rata FS $=10 / 2=5,00$ & \\
Rata-Rata CA $=-5 / 3=-1,67$ & \\
Kordinator Vektor Arah & \\
Sumbu X $=-1.67+4.00=2.33$ & \\
Sumbu Y $=-3.50+5.00=1.50$ & \\
\hline
\end{tabular}

Sumber: Hasil Pengolahan Data (2009)

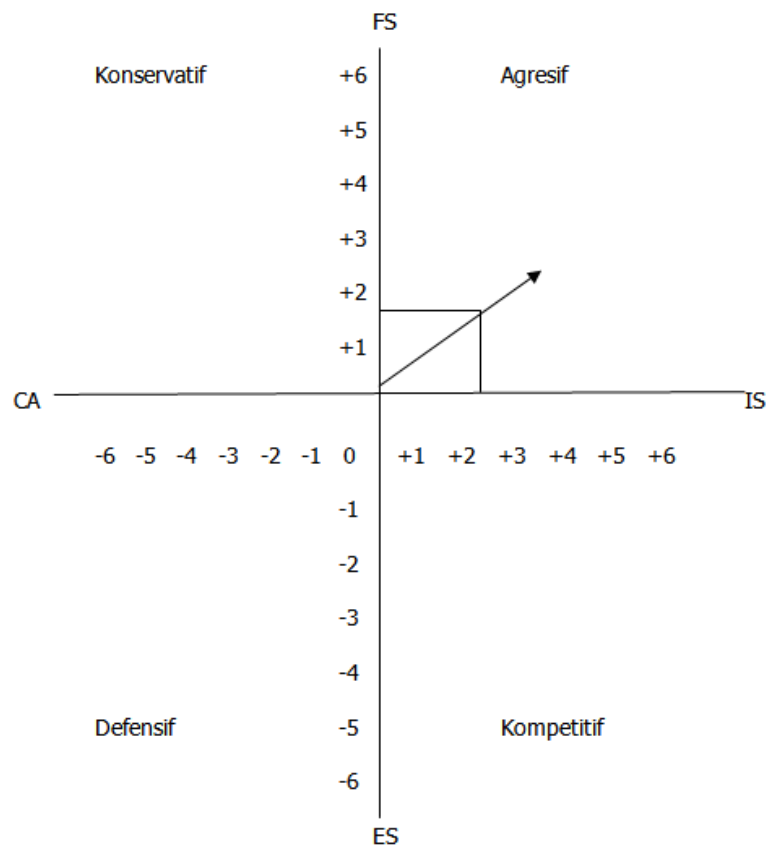

Sumber: Hasil Penelitian (2009)

Gambar 3 Hasil Matriks SPACE PT Wirapati Garuda Paksi 


\section{Matriks Internal Eksternal (IE)}

TOTAL RATA-RATA TERTIMBANG

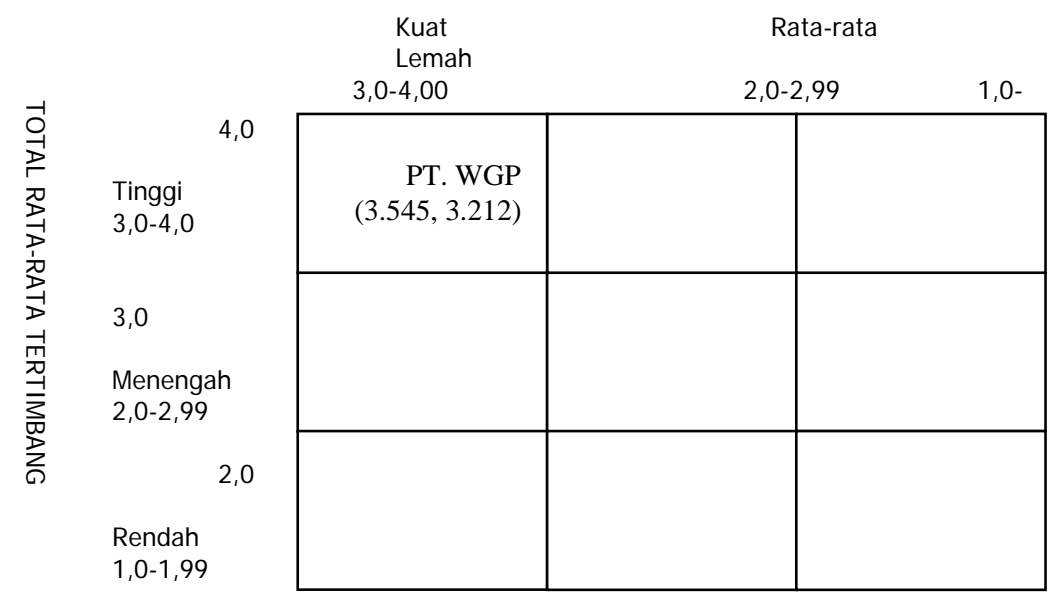

Sumber: Hasil Penelitian (2009)

Gambar 4 Hasil Matriks IE PT. Wirapati Garuda Paksi

\section{Matriks Strategi Besar (Grand Strategy)}

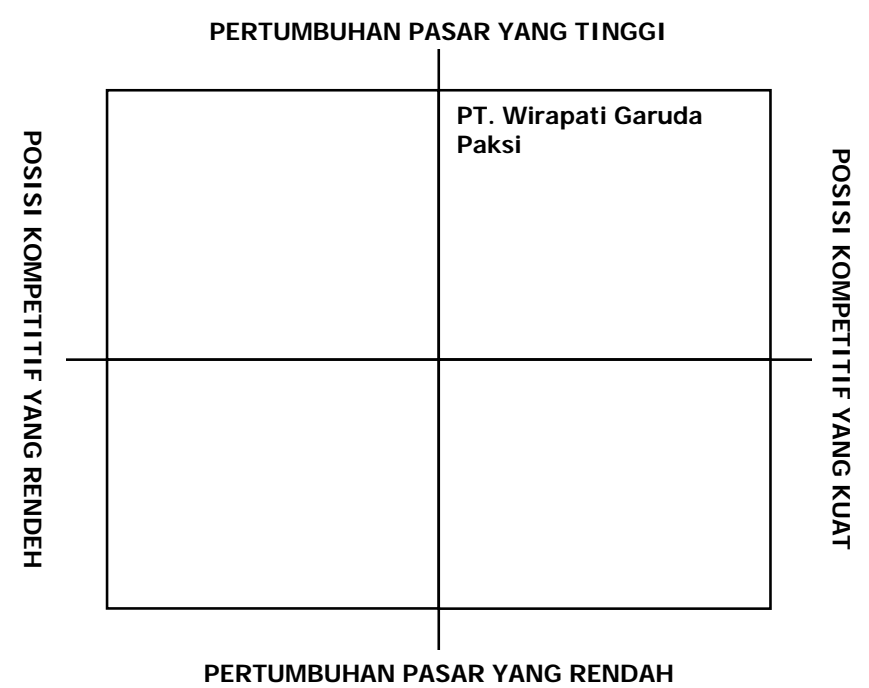

Sumber: Hasil Penelitian (2009)

Gambar Hasil Matriks Grand Strategy PT Wirapati Garuda Paksi 


\section{Kesimpulan Strategi di Tahap Pencocokan (Matching Stage)}

Tabel 7 Kesimpulan Strategi di Tahap Pencocokan / Matching Stage

\begin{tabular}{|c|c|c|c|c|}
\hline No. & $\begin{array}{l}\text { Alternatif } \\
\text { Strategi }\end{array}$ & $\begin{array}{l}\text { Hasil Metode } \\
\text { Analisis } \\
\end{array}$ & $\begin{array}{c}\text { Dievaluasi } \\
\text { dalam QSPM }\end{array}$ & Alasan \\
\hline 1. & Integrasi ke Depan & $\begin{array}{l}\text { SWOT, SPACE, IE, } \\
\text { Grand Strategy }\end{array}$ & $\mathrm{X}$ & $\begin{array}{l}\text { Perusahaan tidak memerlukan } \\
\text { peningkatan terhadap sistem } \\
\text { distribusi/jalur distribusi. }\end{array}$ \\
\hline 2. & $\begin{array}{l}\text { Integrasi ke } \\
\text { Belakang }\end{array}$ & $\begin{array}{l}\text { SPACE, IE, Grand } \\
\text { Strategy }\end{array}$ & $\mathrm{X}$ & $\begin{array}{l}\text { Perusahaan masih dapat } \\
\text { mengandalkan para pemasok (para } \\
\text { sponsor, terutama perusahaan } \\
\text { penyedia tenaga kerja). }\end{array}$ \\
\hline 3. & $\begin{array}{l}\text { Integrasi } \\
\text { Horisontal }\end{array}$ & $\begin{array}{l}\text { SWOT, SPACE, IE, } \\
\text { Grand Strategy }\end{array}$ & $\mathrm{X}$ & $\begin{array}{l}\text { Perusahaan tidak bisa mendapatkan } \\
\text { karakteristik monopolistic dalam } \\
\text { BUJPP ini. }\end{array}$ \\
\hline 4. & Penetrasi Pasar & $\begin{array}{l}\text { SWOT, SPACE, IE, } \\
\text { Grand Strategy }\end{array}$ & V & $\begin{array}{l}\text { Perusahaan harus mencari dan } \\
\text { meningkatkan marketshare yang } \\
\text { lebih besar bagi jasa yang dijualnya. }\end{array}$ \\
\hline 5. & $\begin{array}{l}\text { Pengembangan } \\
\text { Pasar }\end{array}$ & $\begin{array}{l}\text { SWOT, SPACE, IE, } \\
\text { Grand Strategy }\end{array}$ & V & $\begin{array}{l}\text { Perusahaan harus lebih dapat } \\
\text { memperkenalkan jasanya yang } \\
\text { sudah ada pada daerah yang baru. }\end{array}$ \\
\hline 6. & $\begin{array}{l}\text { Pengembangan } \\
\text { Produk }\end{array}$ & $\begin{array}{l}\text { SWOT, SPACE, IE, } \\
\text { Grand Strategy }\end{array}$ & V & $\begin{array}{l}\text { Perusahaan harus dapat } \\
\text { memperbaiki dan melakukan } \\
\text { inovasi yang lain terhadap jasanya. }\end{array}$ \\
\hline 7. & $\begin{array}{l}\text { Diversifikasi } \\
\text { Konsentrik }\end{array}$ & $\begin{array}{l}\text { SWOT, SPACE, } \\
\text { Grand Strategy }\end{array}$ & $\mathrm{X}$ & $\begin{array}{l}\text { BUJPP adalah industri yang tumbuh } \\
\text { dan bergerak dengan cepat. }\end{array}$ \\
\hline 8. & $\begin{array}{l}\text { Diversifikasi } \\
\text { Horisontal }\end{array}$ & SPACE & $\mathrm{X}$ & $\begin{array}{l}\text { BUJPP adalah industri yang tumbuh } \\
\text { dan bergerak dengan cepat. }\end{array}$ \\
\hline 9. & $\begin{array}{l}\text { Diversifikasi } \\
\text { Konglomerasi }\end{array}$ & SPACE & $\mathrm{X}$ & $\begin{array}{l}\text { Perusahaan tidak memiliki modal } \\
\text { yang lebih dan SDM yang } \\
\text { dibutuhkan untuk bersaing di } \\
\text { industri baru. }\end{array}$ \\
\hline
\end{tabular}

\section{Matriks Perencanaan Strategi Kuantitatif (QSPM)}

Setelah melakukan analisis dalam tahap masukan (input stage) menggunakan External Factors Evaluation (EFE), Competitive Profile Matrix (CPM), dan Internal Factors Evaluation (IFE). Dalam tahap pencocokan (matching stage) menggunakan Strength-Weekness-OpportunitiesThreat (SWOT), Strategic Position And Action Evaluation (SPACE), Internal-External (IE), dan Strategi besar (Grand Strategy) didapat strategi yang akan dievaluasi dalam tahap penentuan (decision stage) menggunakan Quantitative Strategic Planning Matrix (QSPM), yaitu Strategi Penetrasi Pasar, Pengembangan Pasar, dan Pengembangan Produk. 
Tabel 8 Matriks QSPM PT. Wirapati Garuda Paksi

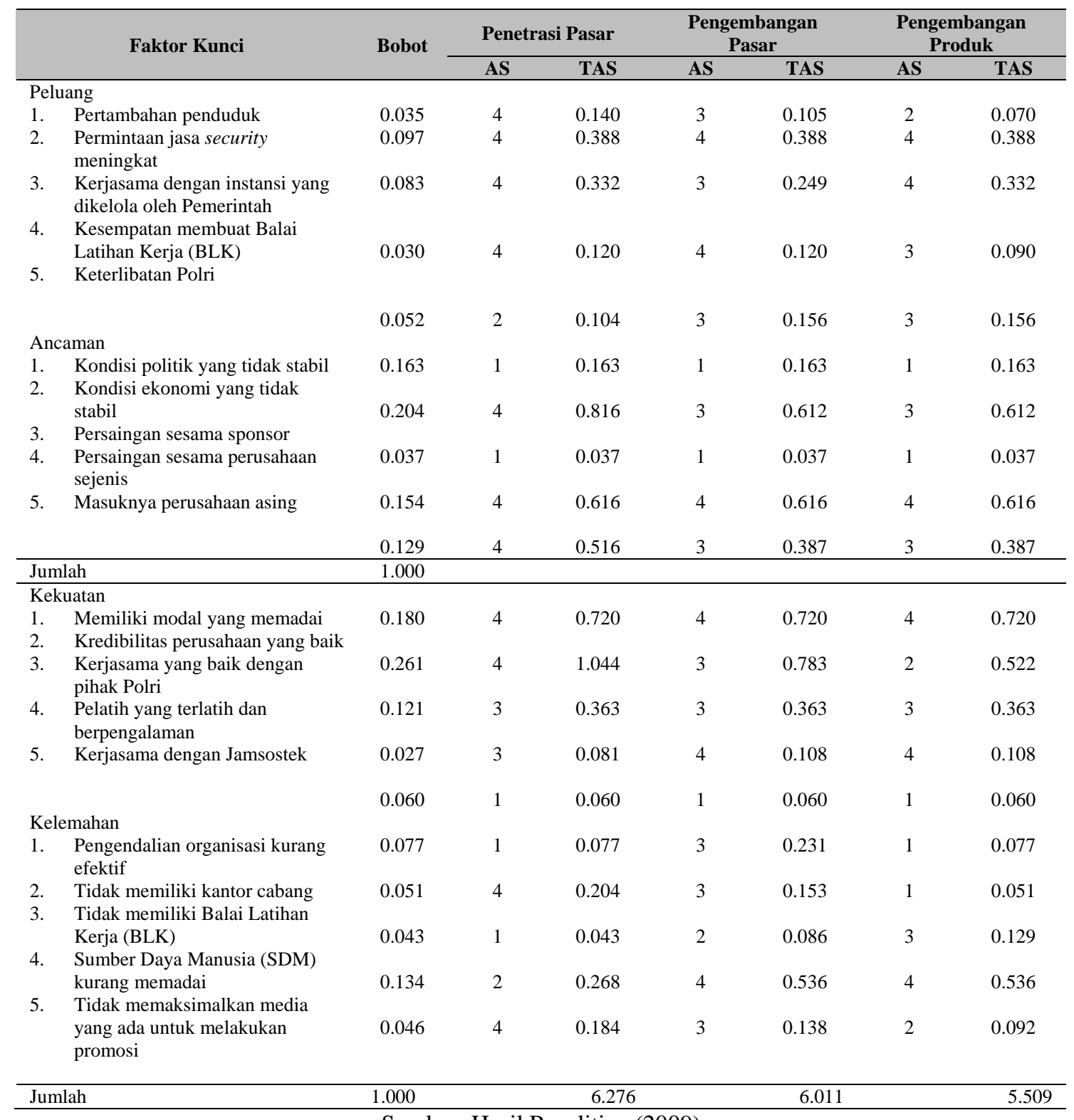

Sumber: Hasil Penelitian (2009)

Berdasarkan Matriks QSPM di atas, dapat dilihat bahwa Jumlah Total Nilai Daya Tarik yang paling besar adalah strategi penetrasi pasar, di mana strategi penetrasi pasar memiliki nilai sebesar 6.276.

Tabel 9 Jumlah Total Nilai Daya Tarik Masing-Masing Alternatif Strategi

\begin{tabular}{llc}
\hline No. & Alternatif Strategi & Jumlah Total Nilai Daya Tarik \\
\hline 1. & Strategi Penetrasi Pasar & 6.276 \\
2. & Strategi Pengembangan Pasar & 6.011 \\
3. & Strategi Pengembangan Produk & 5.509 \\
\hline
\end{tabular}

Sumber: Hasil Penelitian (2009) 
Setelah dievaluasi di dalam matriks QSPM, maka di antara strategi penetrasi pasar, pengembangan pasar, dan pengembangan produk, didapat bahwa strategi penetrasi pasar adalah strategi yang cocok untuk diterapkan oleh PT Wirapati Garuda Paksi. Program-program yang dapat dilakukan PT Wirapati Garuda Paksi dalam strategi penetrasi pasar adalah (1) PT Wirapati Garuda Paksi lebih agresif dalam mempromosikan jasanya dengan menggunakan media yang ada seperti, iklan, pamflet, brosur, $e$-advertising; (2) Melakukan gathering terhadap pelanggan yang menggunakan jasa PT Wirapati Garuda Paksi; (3) Memberikan cinderamata kepada pelanggan PT Wirapati Garuda Paksi; (4) Meminta rekomendasi konsumen yang lain kepada pelanggan PT Wirapati Garuda Paksi.; dan (5) Mengirimkan company profile kepada konsumen yang telah direkomendasikan oleh pelanggan PT Wirapati Garuda Paksi.

\section{SIMPULAN}

Berdasarkan hasil analisis sebelumnya, maka dapat diambil kesimpulan sebagai berikut. Kekuatan (strengths) pada PT Wirapati Garuda Paksi adalah PT Wirapati Garuda Paksi memiliki modal yang memadai, kredibilitas perusahaan yang baik, kerjasama yang baik dengan pihak Polri, pelatih yang terlatih dan berpengalaman serta kerjasama dengan Jamsostek. Kelemahan (weaknesses) pada PT Wirapati Garuda Paksi adalah pengendalian organisasi kurang efektif, tidak memiliki kantor cabang, tidak memiliki Balai Latihan Kerja (BLK), Sumber Daya Manusia (SDM) kurang memadai, dan tidak memaksimalkan media yang ada untuk melakukan promosi. Peluang (opportunities) bagi PT Wirapati Garuda Paksi adalah pertambahan penduduk, permintaan jasa security meningkat, kerjasama dengan instansi yang dikelola oleh pemerintah, kesempatan membuat Balai Latihan Kerja (BLK), dan keterlibatan Polri. Ancaman (threats) bagi PT Wirapati Garuda Paksi adalah kondisi politik yang tidak stabil, kondisi ekonomi yang tidak stabil, persaingan sesama sponsor, persaingan sesama perusahaan sejenis, dan masuknya perusahaan asing.

Dari hasil perhitungan yang dilakukan pada tahap masukan (input stage), didapatkan nilai EFE senilai 3.212. Ini mengindikasikan bahwa PT Wirapati Garuda Paksi di atas rata-rata dalam upayanya untuk menjalankan strategi yang memanfaatkan peluang dan menghindari ancaman eksternalnya. Dari hasil perhitungan yang dilakukan pada tahap masukan (input stage), didapatkan nilai CPM PT Wirapati Garuda Paksi dengan Total Nilai Tertimbang senilai 3.586. Sedangkan PT Risk Management Advisory berada di bawah PT Wirapati Garuda Paksi dengan Total Nilai Tertimbang senilai 2.950 yang merupakan perusahaan terlemah secara keseluruhan dan PT ISS Facility berada di atas PT Wirapati Garuda Paksi dengan Total Nilai Tertimbang senilai 4.084 yang merupakan perusahaan terkuat secara keseluruhan. Dari hasil perhitungan yang dilakukan pada tahap masukan (input stage), didapat nilai EFE senilai 3.545. Ini mengindikasikan bahwa PT Wirapati Garuda Paksi di atas rata-rata dalam seluruh kekuatan internalnya.

Alternatif strategi yang dihasilkan pada tahap pencocokan (matching stage) dengan menggunakan matriks SWOT, SPACE, IE, dan Grand Strategy adalah strategi integrasi ke depan, integrasi ke belakang, integrasi horisontal, penetrasi pasar, pengembangan pasar, pengembangan produk, diversifikasi konsentrik, diversifikasi konglomerat dan diversifikasi horisontal. Tetapi, setelah disesuaikan dengan keadaan perusahaan, maka strategi yang layak dievaluasi dalam matriks QSPM adalah strategi penetrasi pasar, pengembangan pasar dan pengembangan produk. Berdasarkan hasil pengolahan data melalui Matriks QSPM pada tahap keputusan (decision stage), maka terlihat strategi penetrasi pasar lebih menarik untuk di terapkan oleh PT Wirapati Garuda Paksi dengan Jumlah Total Nilai Daya Tarik senilai 6.276, diikuti oleh strategi penetrasi pasar dengan Jumlah Total Nilai Daya Tarik senilai 6.011, dan strategi pengembangan produk dengan Jumlah Total Nilai Daya Tarik senilai 5.509 . 


\section{DAFTAR PUSTAKA}

David, F.R. (2006). Manajemen strategis - konsep, edisi sepuluh, Jakarta: Salemba Empat.

Rangkuti, F. (2009). Analisis SWOT: teknik membedah kasus bisnis, cetakan keenambelas, Jakarta: PT Gramedia Pustaka Utama.

Sugiyono. (2006). Statistika untuk penelitian, cetakan kesembilan, Bandung: CV Alfabeta.

Umar, H. (2008). Strategic management in action, cetakan kelima, Jakarta: PT Gramedia Pustaka Utama.

Wheelen, T.L., and Hunger, J.D. (2008). Strategic management and business policy, $11^{\text {th }}$ ed., Upper Saddle River, New Jersey: Pearson Education, Inc. 